\title{
LA RESPONSABILIDAD PATRIMONIAL DEL ESTADO DE CHILE: UNA REVISIÓN PANORÁMICA DESPUÉS DE CASI VEINTE AÑOS DE JURISPRUDENCIA DE LA CORTE SUPREMA ${ }^{1}$
}

\author{
JUAN CARLOS FERRADA BÓRQUEZ \\ Universidad de Valparaíso \\ Profesor titular de Derecho Administrativo
}

Cómo citar/Citation

Ferrada Bórquez, J. C. (2020).

La responsabilidad patrimonial del Estado de Chile: una revisión panorámica después de casi veinte años de jurisprudencia de la Corte Suprema. Revista de Administración Pública, 211 , 373-406. doi: https://doi.org/10.18042/cepc/rap.211.15

\section{Resumen}

Este trabajo realiza un análisis del sistema de responsabilidad patrimonial de la Administración del Estado en el derecho chileno en referencia al derecho comparado. Así, este artículo revisa los sistemas que han operado en Chile y cómo la jurisprudencia de la Corte Suprema ha determinado que el sistema imperante en nuestro país es la responsabilidad por falta de servicio, haciendo mención de algunos problemas de este régimen y las reglas de prescripción aplicables a las acciones

1 Este trabajo se presentó originalmente en el «Seminario Internacional la Responsabilidad Patrimonial en México: avances y retos», celebrado en Ciudad de México, los días 15 y 16 de noviembre de 2018, y organizado por el Centro de Investigación y Docencia Económicas (CIDE), el Instituto Tecnológico de Estudios Superiores de Monterrey (ITESM) y la Suprema Corte de Justicia de la Nación (SCJN). Agradezco a los organizadores la oportunidad que tuve de debatir con compañeros de distintos países estas ideas, que revisé y corregí a partir de las observaciones recibidas. 
derivadas del mismo. Finalmente, se plantean las excepciones a ese sistema, con especial mención a las hipótesis de responsabilidad objetiva y derechos humanos, y las diferencias con el régimen general.

\section{Palabras clave}

Responsabilidad patrimonial; falta de servicio; falta; culpa; Chile.

\section{Abstract}

This work carries out an analysis of the patrimonial responsibility system of the State Administration in chilean law by reference to comparative law. So this article reports the systems that have operated in Chile and how the jurisprudence of the Supreme Court has determined that the prevailing system in our country is the responsibility for lack of service, mentioning some problems of this regime and the prescription rules applicable to the actions derived from it. Finally, the exceptions to this system are raised, with special mention to the hypothesis of objective responsibility and human rights in the Chilean legal system, and the differences with the general regime.

\section{Keywords}

Patrimonial responsibility; Lack of service; Fault; Culpability; Chile. 


\section{SUMARIO}

I. PALABRAS INICIALES. II. A MODO DE INTRODUCCIÓN: EL SISTEMA DE RESPONSABILIDAD DEL ESTADO Y SU VINCULACIÓN CON LOS FINES U OBJETIVOS

DE LA MISMA: 1. Los fines $u$ objetivos de la responsabilidad civil. 2. La opción adoptada por algunos ordenamientos jurídicos de referencia. III. EI SISTEMA DE RESPONSABILIDAD DEL ESTADO EN CHILE: 1. Las características generales del sistema de responsabilidad del Estado en el derecho chileno. 2. La aplicación del régimen general de la "falta de servicio» a todos los órganos del Estado en el derecho chileno. 3. El contenido de la «falta de servicio» como criterio clave de imputación de responsabilidad. 4. La responsabilidad por "falta de servicio» en la actividad administrativa formal. 5. El rechazo a la responsabilidad sin falta en el ordenamiento jurídico chileno. 6. Los regímenes especiales de responsabilidad en el derecho chileno. IV. LOS DAÑOS INDEMNIZABLES POR RESPONSABILIDAD DEL ESTADO: 1. El daño material. 2. El daño moral. 3. El daño como «pérdida de chance». V. LA PRESCRIPCIÓN DE LA ACCIÓN INDEMNIZATORIA: 1. La regla general del Código Civil. 2. La excepcionalidad en materia de derechos humanos. VI. A MODO DE CONCLUSIÓN.

\section{PALABRAS INICIALES}

Hace quince años (2004) tuve la oportunidad de reflexionar sobre el antiguo pero inagotable tema de la responsabilidad del Estado. Este trabajo está contenido en un libro en el que tuve el honor de participar junto a los distinguidos profesores Mir Puigpelat, Valdivia Olivares, Elgassi, Roldán Xopa y Marín González ${ }^{2}$. En dicha oportunidad se nos invitó a exponer, atendida la entrada en vigor en México de la reforma constitucional de 2002, que consagró precisamente en su Carta Fundamental (art. 113) la responsabilidad objetiva y directa del Estado, siguiendo en ello muy de cerca al derecho español.

2 J. C. Marín González (comp.) (2004), La responsabilidad patrimonial del Estado, México: Porrúa. 
Por el contrario, en Chile en esa época (2004), ámbito en el que centré mi ponencia, se empezaba a consolidar en la jurisprudencia el abandono de la tesis dominante de la responsabilidad objetiva, la que había sido reconocido por los tribunales chilenos desde mediados de la década de los 80 del siglo XX, siguiendo principalmente a los profesores de la Universidad de Chile Soto, Fiamma y Caldera. Así, la Corte Suprema chilena, a partir del año 2002, siguiendo ahora al profesor Pierry y a otros profesores de Derecho Administrativo y de Derecho Civil, comenzó a afirmar que el régimen general de responsabilidad del Estado en el derecho chileno era por falta o culpa, y no uno objetivo, como venía sosteniéndose por la jurisprudencia hasta esa fecha. De este modo, haciendo una aplicación —o reinterpretación — del art. 44 (hoy 42) de la Ley Orgánica Constitucional de Bases Generales de la Administración del Estado (en adelante, LOCBGAE), rechazó la tesis de la responsabilidad objetiva del Estado, la que se había construido sobre la base de la interpretación de normas constitucionales, legales y principios generales, afirmando ahora la existencia de un régimen general de responsabilidad por culpa o "falta de servicio».

Han pasado casi veinte años, y la jurisprudencia de la Corte Suprema ha sido abundante en el mismo sentido que se planteó en el año 2002, afirmando ahora categóricamente que el criterio de imputación general de responsabilidad del Estado en Chile es la "falta de servicio», elemento que se considera indispensable para que surja la obligación de este de reparar los daños que sufren los particulares producto de la actividad o inactividad estatal. Así, solo en la medida que se acredite dicha falta, es decir, un funcionamiento deficiente, tardío o no funcionamiento - tomando como referencia la triada de situaciones que establece la doctrina y jurisprudencia francesa-, el Estado debe reparar los dańos que causa, rechazando por contra las demandas que se fundan en la mera actividad regular de este.

De este modo, no existe a estas alturas ya en el derecho chileno discusión sobre cuál es el régimen general de responsabilidad del Estado, lo que además es respaldado por la amplia mayoría de la doctrina. Por el contrario, la discusión actual, como se verá a continuación, se centra en la comprensión exacta de este régimen de responsabilidad por falta, los elementos que configuran la «falta de servicio» como criterio de imputación de responsabilidad estatal y sus particularidades en ciertos ámbitos específicos, sin dejar de plantearse algunos cuestionamientos a su aplicación estricta y sin excepciones que hace la jurisprudencia.

En este contexto, en este trabajo trataré de hacer un breve repaso del desarrollo que ha tenido el sistema de responsabilidad del Estado en el derecho chileno en los últimos veinte años, su estado actual y algunas discusiones específicas a que ha dado lugar en el último tiempo. En particular, abordaré los alcances que tiene para la doctrina y jurisprudencia chilena la «falta de servicio» como criterio de imputación de responsabilidad al Estado, el rechazo absoluto que hace la jurisprudencia a la responsabilidad sin falta, los daños indemnizables por el Estado en los casos de responsabilidad patrimonial de este y la aplicación de las reglas de prescripción 
a la acción indemnizatoria, en especial en materia de violaciones a los derechos humanos.

\section{A MODO DE INTRODUCCIÓN: EL SISTEMA DE RESPONSABILIDAD DEL ESTADO Y SU VINCULACIÓN CON LOS FINES U OBJETIVOS DE LA MISMA}

\section{LOS FINES U OBJETIVOS DE LA RESPONSABILIDAD CIVIL}

El régimen de responsabilidad civil es la expresión formal de ciertos fines u objetivos que se plantea el ordenamiento jurídico en este ámbito. En este sentido, como señala Barros, la pregunta por los fines se asocia al método o las finalidades que se proponen al ordenamiento jurídico con el régimen de responsabilidad que se pretende instaurar o que ya se encuentra vigente, perspectiva esta última que tiene gran relevancia para comprender las opciones legislativas o judiciales que se quieren alcanzar en este ámbito ${ }^{3}$. Así, los fines que se pretenden conseguir a través de un sistema de responsabilidad constituyen una definición de política pública, que debiera corresponder normalmente al legislador, aunque a menudo intervienen los jueces en su aplicación a un caso concreto.

En este contexto, el legislador, en el momento de establecer las normas que regulan el régimen de responsabilidad civil o patrimonial del Estado, de forma general o en ámbitos específicos, debiera perseguir ciertas finalidades, más allá de la reparatoria o compensatoria, que posee cualquier régimen en esta materia ${ }^{4}$. Así, el establecimiento de un régimen de responsabilidad podrá tener también una finalidad preventiva más o menos explícita, en la medida que imponga consecuencias gravosas para el sujeto que realice ciertos actos irregulares o no deseados que generan dańos a un tercero. Esto, en el ámbito de la responsabilidad del Estado, supone tratar de evitar ciertas actuaciones de los órganos del Estado que se estiman inconvenientes, imponiéndole la obligación de reparar los daños que provoquen en el caso que se realicen.

Algo similar ocurre con las finalidades demarcatoria y de control social, reconocidas por cierto también por la doctrina ${ }^{5}$, en la medida que establecen una obligación reparatoria en caso de ciertas conductas ilícitas o contrarias al ordenamiento jurídico, controlando así socialmente ciertas acciones o inacciones de los poderes públicos.

3 E. Barros Bourie (2006), Tratado de Responsabilidad Extracontractual, Santiago: Editorial Jurídica de Chile, págs. 33-35.

4 O. Mir Puigpelat (2002), La responsabilidad patrimonial de la Administración. Hacia un nuevo sistema, Madrid: Civitas, págs.131 y ss.

5 Mir (2002: 146 y ss.). 
Ahora bien, es evidente que estas finalidades preventiva, demarcatoria y de control social del régimen de responsabilidad se satisfacen de mejor manera en los regímenes de responsabilidad construido sobre la falta o falla del servicio público o del órgano estatal, ya que solo en la medida que se produzca aquella se generará la obligación reparatoria de este. Así, en el caso de que el Estado ajuste su comportamiento a las reglas establecidas en el propio ordenamiento, este, en principio, no estará obligado a reparar los eventuales daños que provoque su actividad, aun cuando proviniera de su acción o inacción.

La situación es diametralmente distinta en los denominados regímenes de responsabilidad objetiva o estricta, en los que el Estado tendrá, en principio, la obligación reparatoria general una vez generado el daño al particular, independientemente de que su actuación se haya ajustado o no al ordenamiento jurídico. En efecto, en estos regímenes de responsabilidad no existe tan claramente un incentivo a la prevención, o al menos en los mismos términos que en un régimen de responsabilidad por falta, ya que la actuación del Estado de acuerdo a las reglas que impone el ordenamiento jurídico no evita su obligación reparatoria, en la medida que descansa en el daño que se provoca en un sujeto que no está obligado a soportarlo.

Sin perjuicio de lo anterior, los regímenes de responsabilidad también pueden tener otras finalidades, entre las que se cuentan la redistributiva y de seguridad social, objetivos que no necesariamente están asociados a un régimen de responsabilidad patrimonial del Estado, pero que pueden vincularse a este ${ }^{6}$. Así, por ejemplo, el régimen de responsabilidad estatal puede pretender distribuir los riesgos y dańos entre todos los integrantes de la comunidad nacional, operando aquel como un sistema redistributivo de estos o de seguridad social, independientemente de que la actuación del órgano o servicio público se ajustó o no al ordenamiento jurídico.

Es evidente que estas finalidades redistributivas y de seguridad social se encuentran más claramente recogidas en los regímenes objetivos de responsabilidad patrimonial del Estado y no en los de falta o culpa, en la medida que lo relevante, como ya se señaló, es el daño producido, y no la actuación lícita o ilícita del órgano o servicio público.

\section{LA OPCIÓN ADOPTADA POR ALGUNOS ORDENAMIENTOS JURÍDICOS DE REFERENCIA}

En el contexto antes descrito, el legislador de cada país opta por alguna(s) de las finalidades u objetivos antes reseñados, diseñando normativamente un régimen de responsabilidad del Estado que satisfaga de mejor manera aquellos. En este sentido, la opción más clara es aquella que se produce en la configuración de

$6 \operatorname{Mir}(2002: 242$ y ss.). 
un régimen de responsabilidad por falta o culpa o, por el contrario, por uno de carácter objetivo.

Ejemplos del primer tipo son, sin duda, los regímenes generales de responsabilidad establecidos en el derecho francés, italiano, alemán, colombiano y chileno, por nombrar algunos, en los que la actuación ilícita, anormal o irregular del servicio u órgano público es la condición indispensable para atribuir responsabilidad patrimonial al Estado. Así, la falta, culpa o falla del servicio público es el criterio jurídico de imputabilidad de la responsabilidad estatal, debiendo el particular acreditar aquella para establecer esta.

Sin duda, el derecho francés constituye el icono en esta materia, en la medida que configuró un régimen de responsabilidad por falta o culpa, siguiendo en ello muy de cerca lo establecido en su propio Código Civil. Así, en sucesivas sentencias del Tribunal de Conflictos y del Consejo de Estado, la jurisprudencia gala construyó un régimen de responsabilidad del Estado sobre la base de la falta o culpa ${ }^{7}$. En este sentido, como señala $\mathrm{Vedel}^{8}$, la "falta» es el fundamento de la responsabilidad pública en Francia, pudiendo corresponder a una falta de servicio o una falta personal vinculada al servicio público.

Ahora bien, esta falta o culpa se identifica con el incumplimiento del servicio público a sus obligaciones, la que puede consistir, a la luz de los casos resueltos por la justicia administrativa, en un defecto de la organización, en un fallo de su funcionamiento o la mera ilegalidad de la actuación administrativa ${ }^{9}$. En todo caso, esta responsabilidad estatal se construye a partir de un juicio de reproche en contra de la Administración, por haber infringida esta un estándar para la prestación del servicio ${ }^{10}$. Así, en principio, no existirá responsabilidad del Estado si no se acredita la falta o infracción a las obligaciones del servicio, sin perjuicio de reconocer el propio ordenamiento, por vía jurisprudencial y legal, algunos supuestos de responsabilidad sin falta u objetiva, como las derivadas de ciertos riesgos especiales creados por el Estado, la ejecución de acciones de colaboración con los servicios públicos o la ruptura de la igualdad ante las cargas públicas ${ }^{11}$.

Este modelo ha sido seguido en otros ordenamientos europeos como el italiano o alemán, en los que, sin embargo, la culpa ha sido la piedra angular sobre la que se ha construido el régimen de responsabilidad civil — probablemente por la aplicación que hace de algunos principios y normas del Código Civil—, aunque adaptada a la imputación de la misma a los órganos del Estado ${ }^{12}$.

7 R. Chapus (1990), Droit Administratif Géneral, tomo I, $5^{\mathrm{a}}$ ed., Paris: Montchrétien, págs. 1293-1294.

8 G. Vedel (1981), Derecho Administrativo, Madrid: Aguilar, págs. 303-304.

9 Ibid.

10 J. M. Valdivia (2004), «La responsabilidad de la administración del Estado en Francia», en La responsabilidad patrimonial del Estado, México: Porrúa, págs. 56-57.

11 R. Chapus (2001: 1335 y ss.).

$12 \operatorname{Mir}(2002: 177-181)$. 
En nuestro medio latinoamericano, este modelo de responsabilidad por falta o culpa también ha sido recogido en algunos ordenamientos, como el caso colombiano o chileno. En el primero, el derecho colombiano, la responsabilidad del Estado se ha construido históricamente a partir del concepto de «falla de servicio", sin perjuicio de sus antecedentes más remotos en algunas normas del Código Civil. Así, la jurisprudencia de la Corte Suprema primero y del Consejo de Estado después, consolidaron un régimen de responsabilidad extracontractual del Estado sobre la base de imputar a este las fallas en el servicio público como causa directa de los daños sufridos por los particulares, considerando dentro de aquellas no actuar debiendo hacerlo, actuar en forma incorrecta o indebida o actuar tardíamente ${ }^{13}$.

Más modernamente, la Constitución de 1991 (art. 90) ${ }^{14}$ recoge esta jurisprudencia, estableciendo la responsabilidad del Estado por los daños antijurídicos que le son imputables, sin perjuicio de extenderse aquella a los daños derivados de actuaciones dolosas o culposas de los agentes públicos. Esto se ve complementado con lo establecido en el art. 140 del Código de Procedimiento Administrativo y de lo Contencioso Administrativo, que establece la reparación directa de los daños antijurídicos provenientes de la acción de los agentes del Estado ${ }^{15}$. Esto ha dado lugar a una ampliación progresiva de las causales de imputabilidad de responsabilidad patrimonial del Estado, no agotándose ahora en la falla de servicio, sino también en la imposición de la obligación reparatoria del Estado proveniente de actividades riesgosas o aun como mera aplicación de la responsabilidad obje-

13 J. Tamayo (2014), La responsabilidad del Estado, Bogotá: Biblioteca Jurídica Diké, págs. 19-32.

14 El art. 90 de la Constitución colombiana de 1991 establece: «El Estado responderá patrimonialmente por los daños antijurídicos que le sean imputables, causados por la acción o la omisión de las autoridades públicas. En el evento de ser condenado el Estado a la reparación patrimonial de uno de tales dańos, que haya sido consecuencia de la conducta dolosa o gravemente culposa de un agente suyo, aquél deberá repetir contra éste».

15 El art. 140 del Código de Procedimiento Administrativo y de lo Contencioso Administrativo establece lo siguiente: «Reparación directa. En los términos del art. 90 de la Constitución Política, la persona interesada podrá demandar directamente la reparación del daño antijurídico producido por la acción u omisión de los agentes del Estado. De conformidad con el inciso anterior, el Estado responderá, entre otras, cuando la causa del daño sea un hecho, una omisión, una operación administrativa o la ocupación temporal o permanente de inmueble por causa de trabajos públicos o por cualquiera otra causa imputable a una entidad pública o a un particular que haya obrado siguiendo una expresa instrucción de la misma. Las entidades públicas deberán promover la misma pretensión cuando resulten perjudicadas por la actuación de un particular o de otra entidad pública. En todos los casos en los que en la causación del daño estén involucrados particulares y entidades públicas, en la sentencia se determinará la proporción por la cual debe responder cada una de ellas, teniendo en cuenta la influencia causal del hecho o la omisión en la ocurrencia del daño». 
tiva, cuestión esta última que genera mucha controversia en la propia doctrina colombiana ${ }^{16}$.

$\mathrm{Al}$ contrario, hay otros ordenamientos que han optado por regímenes de responsabilidad objetiva, probablemente con la finalidad de dar mayor cobertura a la responsabilidad estatal. Ejemplo prototípico de esto es el régimen español, en que producto de una evolución legislativa desde mediados del siglo XX fue consolidando un modelo de responsabilidad objetiva del Estado hasta su pleno reconocimiento en el año 1992 (García de Enterría y Fernández, 1996). En efecto, la Ley de Expropiación Forzosa de 1954 primero ${ }^{17}$ y la Ley de Régimen Jurídico de la Administración del Estado de $1957^{18}$ después —y en cierto sentido también la Constitución española de 1978, aunque en términos más amplios ${ }^{19}$ - , sirvieron de base para el establecimiento más reciente (Ley de Régimen Jurídico de las Administraciones Públicas y del Procedimiento Administrativo Común 30/1992, en adelante LRJAP y PAC) de un régimen objetivo de responsabilidad del Estado en el derecho español ${ }^{20}$, el que ha sido ratificado recientemente en la Ley del Régimen Jurídico del Sector Público 40/2015²1.

16 Tamayo (2014: 35 y ss.).

17 El art. 121.1 de esta ley señala lo siguiente: «Dará también lugar a indemnización con arreglo al mismo procedimiento toda lesión que los particulares sufran en los bienes y derechos a que esta Ley se refiere, siempre que aquélla sea consecuencia del funcionamiento normal o anormal de los servicios públicos, o la adopción de medidas de carácter discrecional no fiscalizables en vía contenciosa, sin perjuicio de las responsabilidades que la Administración pueda exigir de sus funcionarios con tal motivo".

18 El art. 40.1 de esta ley señala lo siguiente: «Los particulares tendrán derecho a ser indemnizados por el Estado de toda lesión que sufran en cualquiera de sus bienes y derechos, salvo en los casos de fuerza mayor, siempre que aquella lesión sea consecuencia del funcionamiento normal o anormal de los servicios públicos o de la adopción de medidas no fiscalizables en vía contenciosa».

19 El art. 106.2 de la Constitución española señala que: «Los particulares, en los términos establecidos por la ley, tendrán derecho a ser indemnizados por toda lesión que sufran en cualquiera de sus bienes y derechos, salvo en los casos de fuerza mayor, siempre que la lesión sea consecuencia del funcionamiento de los servicios públicos».

20 El art. 139 de la Ley 30/1992 LRJAP y PAC establece en su numeral $1^{\circ}$ que «los particulares tendrán derecho a ser indemnizados por las Administraciones Públicas correspondientes, de toda lesión que sufran en cualquiera de sus bienes y derechos, salvo en los casos de fuerza mayor, siempre que la lesión sea consecuencia del funcionamiento normal o anormal de los servicios públicos», añadiendo el también numeral $1^{\circ}$ del art. 141 que «sólo serán indemnizables las lesiones producidas al particular provenientes de daños que éste no tenga el deber jurídico de soportar de acuerdo con la Ley. No serán indemnizables los daños que se deriven de hechos o circunstancias que no se hubiesen podido prever o evitar según el estado de los conocimientos de la ciencia o de la técnica existentes en el momento de producción de aquéllos, todo ello sin perjuicio de las prestaciones asistenciales o económicas que las leyes puedan establecer para estos casos».

21 El art. 32.1 de la Ley 40/2015, Régimen jurídico del sector público, dispone que: «Los particulares tendrán derecho a ser indemnizados por las Administraciones Públicas corres- 
La doctrina española se ha sentido tradicionalmente orgullosa de este régimen jurídico de responsabilidad, llegando a catalogarlo como el más avanzado de Europa $^{22}$. Sin embargo, han existido algunas voces críticas ${ }^{23}$, las que han tenido un nuevo impulso a partir de los excelentes trabajos de Pantaleón ${ }^{24}$ y Mir $^{25}$ sobre la materia, los que han cuestionado el carácter solidario, eficiente y redistributivo del sistema. Esto ha llevado a la doctrina española clásica a modular su posición original, señalando que la aplicación general y absoluta que se ha hecho de las normas de responsabilidad de la Administración no se ajusta a la intención original, siendo esto insostenible objetivamente y requiriendo una urgente modificación ${ }^{26}$.

No obstante lo expuesto, algunos ordenamientos jurídicos latinoamericanos han seguido este modelo español, consagrando también la responsabilidad objetiva del Estado como régimen general de responsabilidad. Esto ha ocurrido en Argentina con la Ley 26.944 de 2014, que establece precisamente que «la responsabilidad del Estado es objetiva y directa» (art. $1^{\circ}$ ), aunque a continuación la misma ley se encarga de precisar que esta deriva, por regla general, de la existencia de una actividad o inactividad ilegítima (art. $3^{\circ}$ ). No obstante, la ley argentina permite la responsabilidad por actividad legítima o lícita, pero en tal caso exige la concurrencia de los requisitos de ausencia de deber jurídico de soportar el daño y la existencia de un sacrificio especial (art. 5\%).

En el caso peruano, existe una regulación (Ley 27.444 de 2001) que también parece apuntar a un sistema de responsabilidad objetiva del Estado, excluyendo esta por caso fortuito o fuerza mayor, hecho determinante del administrado, damnificado o tercero o se trate de daños que el administrado tiene el deber jurídico de soportar (art. 258).

pondientes, de toda lesión que sufran en cualquiera de sus bienes y derechos, siempre que la lesión sea consecuencia del funcionamiento normal o anormal de los servicios públicos salvo en los casos de fuerza mayor o de daños que el particular tenga el deber jurídico de soportar de acuerdo con la Ley». A esto, el art. 34.1 de la misma ley agrega que: «Sólo serán indemnizables las lesiones producidas al particular provenientes de daños que éste no tenga el deber jurídico de soportar de acuerdo con la Ley. No serán indemnizables los daños que se deriven de hechos o circunstancias que no se hubiesen podido prever o evitar según el estado de los conocimientos de la ciencia o de la técnica existentes en el momento de producción de aquéllos, todo ello sin perjuicio de las prestaciones asistenciales o económicas que las leyes puedan establecer para estos casos».

22 E. García de Enterría y T.-R. Fernández (1997), Curso de Derecho Administrativo, tomo II, Madrid: Civitas, pág. 371.

23 F. Garrido Falla (1982), Tratado de Derecho Administrativo, vol. II, Madrid: Centro de Estudios Constitucionales, págs. 241-243.

24 F. Pantaleón Prieto (1994), «Los anteojos del civilista: Hacia una revisión del régimen de responsabilidad patrimonial de las Administraciones públicas», Documentación Administrativa, 237-238, págs. 239-253.

25 Mir (2002).

26 E. García de Enterría (2002: 19-23). 
Este modelo se recoge también, en principio, en el derecho mexicano, que contempla en la Constitución política — a partir de la reforma de 2002 — una regla general en materia de responsabilidad del Estado, seńalando que esta se genera «por los daños que, con motivo de su actividad administrativa irregular, cause en los bienes o derechos de los particulares, [la que] será objetiva y directa. Los particulares tendrán derecho a una indemnización conforme a las bases, límites y procedimientos que establezcan las leyes». Esta regulación es complementada por la Ley Federal de Responsabilidad Patrimonial del Estado de 2004 que afirma que la «responsabilidad extracontractual a cargo del Estado es objetiva y directa, y la indemnización deberá ajustarse a los términos y condiciones señalados en esta Ley y en las demás disposiciones legales a que la misma hace referencia». Sin embargo, la ley citada excluye la responsabilidad del Estado por los daños que se generen por caso fortuito o fuerza mayor, riesgos del desarrollo o actividad administrativa regular, referencia esta última que pareciera llevar a que la obligación reparatoria del Estado solo surge a partir de la actividad irregular de este y no es meramente objetiva.

Como puede observarse, y más allá de las discrepancias que existen en la doctrina sobre qué debe entenderse por responsabilidad objetiva del Estado, es claro que la opción hecha por este régimen en los países latinoamericanos no es totalmente consistente con el modelo español, en la medida que la fuente de la responsabilidad es, por regla general, la actividad ilícita o irregular. Solo excepcionalmente se admite —en el derecho argentino expresamente — la responsabilidad del Estado por actividad lícita, regular o normal —en los términos utilizados por la ley española-, siendo la actuación del órgano público en contravención del orden jurídico lo que genera la obligación reparatoria de los dańos que provoca aquella.

\section{EL SISTEMA DE RESPONSABILIDAD DEL ESTADO DE CHILE}

\section{LAS CARACTERÍSTICAS GENERALES DEL SISTEMA DE RESPONSABILIDAD DEL ESTADO EN EL DERECHO CHILENO}

En el derecho chileno se sostiene que, a partir de lo dispuesto en los arts. $6^{\circ}$ y $7^{\circ}$ de la Constitución Política de la República, existe la obligación de todos los órganos del Estado —incluida la Administración del Estado - de someterse a esta y a las demás dictadas conforme a aquella, lo que en caso de contravención dará lugar a las responsabilidades y sanciones que determine la ley. Por supuesto, esto no determina la forma específica de cómo se hará efectiva dicha responsabilidad, pero marcará un principio general en esta materia, cuya regulación corresponderá al legislador ${ }^{27}$.

27 J. C. Ferrada Bórquez (2004), «La responsabilidad patrimonial de la Administración del Estado en Chile: una breve revisión del estado actual de la discusión", en La responsabilidad patrimonial del Estado, México: Porrúa, págs. 110-111. 
En este contexto, la doctrina chilena ${ }^{28}$ formuló desde principios de los años ochenta la tesis de la responsabilidad objetiva del Estado, citando para esto algunas normas constitucionales generales. Así, al disponer por una parte el art. 38 de la Constitución el derecho de los particulares a recurrir a los tribunales en el caso de haber sido lesionado sus derechos ${ }^{29} \mathrm{y}$, por otra, la afirmación en el art. $4^{\circ}$ de la LOCBGAE que el Estado será responsable por los daños que causen los órganos de la Administración del Estado en ejercicio de sus funciones ${ }^{30}$, se construyó por la doctrina la obligación reparatoria de estos, cualquiera que sea la causa específica del daño producido al particular, siempre que esto proviniere de la acción o inacción estatal. Lo anterior fue complementado con el recurso a ciertos principios y reglas generales dispuestas en la Constitución Política, como el carácter republicano del sistema de gobierno, la igualdad ante la ley, la igualdad ante las cargas públicas y la protección del derecho de propiedad, lo que permitió a esa doctrina formular un principio de indemnidad de los particulares frente a la acción estatal y de obligación del Estado de responder frente a todo daño que provocaba su actividad o inactividad ${ }^{31}$.

En este sentido, la doctrina de la época sostuvo, sin muchos fundamentos, que la citada LOCBGAE de 1986 consagró «la existencia de una nueva responsabilidad de Derecho Público, de naturaleza objetiva» ${ }^{32}$, y que para que esta se configure basta «la causalidad material como factor de atribución de la responsabilidad», afirmando que "la falta de servicio», a que se refería el art. 44 de esta ley hacía solo referencia al resultado. Así, «la falta de servicio es la ineficiencia externa del Estado o de los servicios descentralizados», como resultado, pero no un estándar de funcionamiento del servicio público ${ }^{33}$.

28 E. Soto Kloss (1984), «Bases para una teoría general de la responsabilidad extracontractual del Estado en el derecho chileno", XV Jornadas chilenas de Derecho Público, Universidad de Valparaíso, págs. 331-347.

29 El art. 38 inciso $2^{\circ}$ de la Constitución Política de la República, que reconoce más bien el derecho a la acción o tutela judicial más que un régimen de responsabilidad del Estado señala: "Cualquier persona que sea lesionada en sus derechos por la Administración del Estado, de sus organismos o de las municipalidades, podrá reclamar ante los tribunales que determine la ley, sin perjuicio de la responsabilidad que pudiere afectar al funcionario que hubiere causado el daño".

30 El art. 42 actual de la Ley Orgánica Constitucional de Bases Generales de la Administración del Estado señala que: «Los órganos de la Administración serán responsables del daño que causen por falta de servicio. No obstante, el Estado tendrá derecho a repetir en contra del funcionario que hubiere incurrido en falta personal».

31 E. Soto (1984: 331-347).

32 R. Pantoja Bauzá (1986), Bases Generales de la Administración del Estado, Santiago: Editorial Ediar-Conosur Ltda.

33 J. López Santamaría (1998), «Responsabilidad por falta de servicio. Casuística reciente», Cuadernos Jurídicos, 10, Santiago de Chile, Facultad de Derecho, Universidad Adolfo Ibáñez. 
En análogos términos, desde el año 1981 la jurisprudencia de la Corte Suprema comulgó con la tesis del sistema de responsabilidad objetiva, señalando que «la responsabilidad por falta de servicio es una responsabilidad objetiva pues en ella el perjudicado es relevado de probar si hubo culpa o dolo del agente, como también la identidad de éste, bastando acreditar que el perjuicio se debió a un servicio deficiente que el órgano estatal debió subsanar» («Tirado con Municipalidad de La Reina»). Así, una vez calificada la responsabilidad del Estado como objetiva, la Corte Suprema estableció los requisitos que deben concurrir para exigirla, manifestando que «ella procede sólo en caso de que concurran copulativamente dos elementos: a) que haya existido falta de un servicio que la Municipalidad estaba obligada a prestar; y b) que entre esta falta de servicio y el daño producido exista relación de causalidad, resultando este daño consecuencia inmediata y directa de esta falta» («Villegas Lorca con Municipalidad de Providencia», 1993).

Con todo, como se puede apreciar, una vez afirmada la responsabilidad objetiva del Estado, la doctrina y la jurisprudencia chilena establecieron casi siempre como una exigencia adicional para su procedencia la falta o deficiencia en la actuación del servicio público, excluyendo solo la culpa o dolo del agente público. En este sentido, se puede sostener que la objetividad de la responsabilidad, al menos en la jurisprudencia chilena, se planteó respecto de la omisión de culpa del funcionario público, pero no en relación al incumplimiento de una obligación o deber de cuidado de la organización, exigiéndose en la práctica — aunque no en el discurso - la falta o contravención de esta de una regla jurídica para que nazca la obligación reparatoria del Estado.

Solo en contadas ocasiones la jurisprudencia chilena dio lugar a una verdadera responsabilidad del Estado, sin falta de ninguna especie, a partir de la simple actividad lícita del servicio público, lo que fue fundado en criterios de equidad e igualdad ante las cargas públicas, pero sin hacer referencia a la existencia o no de falta del servicio público. El caso más paradigmático en este sentido es el caso «Galletué con Fisco» (1984), sentencia que, en todo caso, es muy controversial en el derecho chileno, ya que impuso una obligación reparatoria del Estado a partir de una limitación legal a la explotación de ciertas especies arbóreas protegidas, las que en último término derivaban de la función social de la propiedad.

Sin embargo, a partir del año 2002 la jurisprudencia de la Corte Suprema, tomando como referencia una doctrina minoritaria hasta ese momento ${ }^{34}$, viene afirmando formalmente la existencia en el derecho chileno de un régimen general de responsabilidad del Estado por falta o culpa, excluyendo expresamente la existencia de un régimen objetivo en este ámbito. Así, a partir de lo expuesto en los mismos arts. $4^{\circ}$ y 42 de la LOCBGAE ya citados, se afirma la existencia de un régimen subjetivo de responsabilidad (o al menos no objetivo) que implica que, para imputar responsabilidad a un órgano administrativo estatal, se debe

34 P. Pierry Arrau (2000), "Algunos aspectos de la responsabilidad extracontractual del Estado por falta de servicio", Revista de Derecho, Consejo de Defensa del Estado, 1, págs. 11-39. 
establecer que la prestación del servicio público no se dio en términos y con los estándares exigidos por la ley, lo que configura precisamente la denominada «falta de servicio». Esto es particularmente claro del tenor del art. 42 antes citado (ex art. 44 de la misma ley), que señala precisamente que «los órganos de la Administración serán responsables del daño que causen por falta de servicio», fórmula que la jurisprudencia ha ido ampliando a otros órganos del Estado, aun cuando no se le aplique directamente esta norma, esto como criterio general de imputación de responsabilidad ${ }^{35}$.

En este sentido, es paradigmática la sentencia de la Corte Suprema del año 2002, "Figueroa con Fisco de Chile», en que la Corte afirma que:

[...] las aludidas normas de los arts. $6^{\circ}$ y $7^{\circ}$ de la Carta Política imponen a los órganos del Estado el deber de observar en su accionar el principio de legalidad que enuncian esas disposiciones y prescriben, en lo que interesa, que la contravención de sus disposiciones generará las responsabilidades que determine la ley y, a su vez, el art. 38 de la misma Constitución concede a toda persona que sea lesionada en sus derechos por la Administración del Estado, de sus organismos o de las municipalidades, el derecho a reclamar ante los tribunales que determine la ley, sin perjuicio de la responsabilidad que pudiere afectar al funcionario que hubiere causado el dańo, lo que permite a la justicia ordinaria conocer de acciones indemnizatorias por actos irregulares de la Administración.

Y luego añade:

Que los preceptos constitucionales relacionados en el motivo anterior, al reconocer el principio de la responsabilidad del Estado, no establecen cuál es la naturaleza de ésta, sino se remiten a la ley para determinarla, lo que hacen los arts. $4^{\circ}$ y 44 de la Ley Orgánica Constitucional No 18.575, al señalar, en general, que el Estado será responsable por los daños que causen los órganos de la Administración en el ejercicio de sus funciones, sin perjuicio de las responsabilidades que pudieren afectar al funcionario que los hubiere ocasionado y, en especial, respecto de los Ministerios y organismos regidos por el Título II del mismo cuerpo legal, que los órganos de la administración serán responsables del daño que causen por falta de servicio y que, no obstante, el Estado tendrá derecho a repetir en contra del funcionario que hubiere incurrido en falta personal.

De lo anterior, la Corte Suprema concluye:

Que, según lo entiende la doctrina, la falta de servicio que irroga directamente responsabilidad al Estado, en los términos del aludido art. 44 de la Carta Constitucional, se produce si sus órganos administrativos no actúan, debiendo hacerlo,

35 C. Román (2016), «Seguel Cares contra Fisco de Chile», en Doctrina y Enseñanza del Derecho Administrativo chileno: Estudios en homenaje a Pedro Pierry Arrau, Valparaíso: Ediciones Universitarias de Valparaíso, págs. 449-476. 
si su actuación es tardía o si ellos funcionan defectuosamente, causando perjuicio a los usuarios o destinatarios del servicio público y que si bien estos últimos no requieren individualizar ni perseguir al funcionario cuya acción u omisión personal origina la falta, en cambio, deben invocar y acreditar la existencia de esta falla en la actividad del órgano administrativo, y que ella es la causa del daño experimentado por el patrimonio de la víctima.

Este criterio ha sido reiterado por la Corte Suprema en todas las sentencias dictadas desde esa época hasta la actualidad, variando solo los alcances de la misma, pero sin cuestionar el carácter subjetivo o por falta que establece el ordenamiento jurídico chileno en materia de responsabilidad del Estado. En este sentido, recientemente la Corte Suprema ha señalado que «la falta de servicio se presenta como una deficiencia o mal funcionamiento del servicio en relación a la conducta normal que se espera de él, estimándose que ello concurre cuando aquel no funciona debiendo hacerlo y cuando funciona irregular o tardíamente, operando así como un factor de imputación que genera la consecuente responsabilidad indemnizatoria» («Olivares con Fisco de Chile», Rol 39.484-2017, 2 de octubre de 2018).

De este modo, la «falta de servicio» se ha constituido en la piedra angular del régimen general de responsabilidad del Estado en el derecho chileno, no generándose obligación reparatoria de este por los daños que cause, sino cuando concurre la falta o culpa del servicio público en la generación del daño. En este contexto, para declarar la procedencia de la responsabilidad extracontractual del Estado en el ordenamiento jurídico chileno, es necesario acreditar en el caso concreto la falta o infracción del servicio público a sus deberes jurídicos ordinarios, no bastando la sola concurrencia de la actividad estatal, el daño y la relación de causalidad entre ambos. Así, si el particular no logra probar dicha falta, el Estado no estará obligado a indemnizar, ya que el daño se habría producido sin infracción al orden jurídico por parte de este, es decir, careciendo del elemento de antijuridicidad en la acción u omisión estatal ${ }^{36}$. Sin prejuicio de lo anterior, también aparece como un título de imputación de responsabilidad del Estado en nuestro derecho la «falta personal», en el caso que ella sea cometida en ejercicio del servicio público o con ocasión del mismo. En efecto, atendido que el párrafo segundo del art. 42 de la LOCBGAE señala que «no obstante, el Estado tendrá derecho a repetir en contra del funcionario que hubiere incurrido en falta personal», la doctrina pareciera sostener que esta última también daría lugar a responsabilidad del Estado, independientemente de la "falta de servicio», configurándola entonces como una hipótesis distinta de esta ${ }^{37}$.

36 J. C. Ferrada Bórquez (2004: 120-125).

37 P. Pierry Arrau (1995), «Repetición del Estado en contra del funcionario», Revista de Derecho, Universidad Católica de Valparaíso, 16. 
Esta tesis ha sido recogida por la jurisprudencia chilena, estableciendo precisamente la «falta personal» como una causal específica de responsabilidad estatal, en aquellos casos en que la actuación del funcionario es en el ejercicio de sus funciones o se vincula con estos. Así, la Corte Suprema seńala que:

[...] el Estado no puede desvincularse de la falta personal en que ha incurrido uno de sus agentes, por cuanto ha sido el mismo Estado quien ha instalado a ambos funcionarios en una determinada misión — de servicio disponible y acuartelados en segundo grado- $-y$ les ha impuesto además la obligación de permanecer en el cuartel, de modo que la acción desplegada por el funcionario Osorio Tapia no se encuentra desprovista de vínculo con el servicio. En efecto, los dos funcionarios residían en la Tenencia dada su condición de carabineros solteros, los dos estaban esa noche allí dado el acuartelamiento dispuesto, por lo que claramente la falta personal de Osorio es de aquellas que dan lugar a la responsabilidad estatal. [Y luego añade:] Que a la noción de falta de servicio, aplicable a las Fuerzas Armadas y Carabineros a través del art. 2314 del Código Civil, se le debe complementar la noción de falta personal, ya que la distinción capital en materia de responsabilidad extracontractual del Estado es precisamente entre falta de servicio y falta personal, la que por lo demás recoge el art. 42 de la Ley de Bases de la Administración del Estado y el art. 141 de la Ley Orgánica Constitucional de Municipalidades. Dicha falta personal compromete la responsabilidad del Estado cuando no se encuentra desprovista de vínculo con la función, lo que ocurre cuando ella se ha cometido en ejercicio de la función o con ocasión de la misma («Morales Gamboa con Fisco de Chile», Rol 7919-2008, 14 de enero de 2011).

Sin embargo, contrariamente a lo que sugiere el fallo antes citado, en mi opinión, la «falta personal» no constituye un título de imputación distinto de la responsabilidad del Estado, sino que forma parte de la misma "falta de servicio", la que considera dentro de sus hipótesis precisamente la actividad culposa o dolosa del agente público en el ejercicio de sus funciones o con ocasión del mismo. Así, la falta personal no sería, a mi juicio, un título de imputación diverso de responsabilidad estatal, sino una manifestación más de la "falta de servicio», sin perjuicio del derecho de repetición que tendría el Estado en contra del funcionario que hubiere cometido la «falta personal».

\section{LA APLICACIÓN DEL RÉGIMEN GENERAL DE LA «FALTA DE SERVICIO» A TODOS LOS ÓRGANOS DEL ESTADO EN EL DERECHO CHILENO}

Como se señaló, este régimen general de responsabilidad por falta está construido en el derecho chileno a partir de lo dispuesto en el actual art. 42 de la LOCBGAE. Esto implica que este régimen jurídico solo se aplica, en principio, a los órganos de la Administración del Estado regidos por dicha disposición, quedando excluidos por tanto un gran número de órganos ajenos al ámbito de aplicación de esta norma. En este sentido, órganos como las Fuerzas Armadas, las Fuerzas de Orden y Seguridad Pública, las Municipalidades o los Gobiernos 
Regionales, en principio, quedan excluidos de la aplicación del art. 42 ya referido y del régimen de responsabilidad por falta contenido en él, ello por expresa disposición legal (art. 21 de la misma LOCBGAE).

No obstante esto, la jurisprudencia de la Corte Suprema, probablemente por influencia doctrinal ${ }^{38}$, ha extendido la aplicación de este régimen de responsabilidad por falta o culpa a estos órganos excluidos, haciendo una aplicación extensiva del principio de responsabilidad por culpa o falta que consagra también el Código Civil. En este sentido, la Corte ha señalado que:

[...] cabe dilucidar qué sistema resulta aplicable a las instituciones excluidas, y en el caso particular a las Fuerzas Armadas; para ello ha de recurrirse al derecho común, teniendo presente que precisamente el desarrollo del derecho administrativo, allí donde ha ocurrido, ha sido a partir de la distinta interpretación de las normas de derecho común para el Estado y para las relaciones entre particulares, permitiendo de esta forma la conciliación de la actuación estatal, dotada de imperio público, como guardiana del interés colectivo, con la protección de los derechos de los ciudadanos, de tal suerte que cabe aceptar la aplicación en nuestro país a partir del art. 2314 del Código Civil, de la noción de falta de servicio. En efecto, al Estado como a los otros entes públicos administrativos pueden serle aplicados de manera diversa las normas del título XXXV del Código Civil, sin que esto implique, desde luego, una errada interpretación de las mismas. Es así que las personas jurídicas son capaces de culpa, aunque carezcan de voluntad propia. La culpa civil, como señalan los hermanos Mazeaud y André Tunc, «no requiere la voluntad, ni siquiera el discernimiento, no es necesariamente una culpa moral; es suficiente con comportarse de manera distinta a la que habría observado en parecidas circunstancias un individuo cuidadoso». De acuerdo con este razonamiento y ampliándolo, puede no exigirse para la responsabilidad de la persona jurídica Estado la culpa o dolo de sus órganos o representantes; basta con que el comportamiento del servicio público fuera distinto al que debiera considerarse su comportamiento normal, o sea basta con probar una falta de servicio. Por otra parte, la culpa de funcionarios anónimos puede presumirse, como ha hecho en ocasiones la jurisprudencia, en estos casos la culpa del órgano, que se presume de los hechos mismos, constituye la culpa del Estado («Seguel Cares con Fisco», Rol 371-2008, 30 de julio de 2009).

Este criterio ha sido reiterado por la Corte Suprema en un fallo reciente («Olivares con Fisco de Chile», Rol 39.484-2017, de 2 de octubre de 2018), confirmando el criterio de aplicación de la «falta de servicio" para la configuración de la responsabilidad de los órganos de la Administración del Estado, aun cuando no se aplique directamente el art. 42 de la LOCBGAE que contiene expresamente este criterio de imputación de responsabilidad, derivando esto del Código Civil o de otras normas de responsabilidad establecidas en el derecho chileno.

Lo mismo puede decirse de la aplicación del mismo criterio de imputación a órganos estatales ajenos a la Administración del Estado, que carecen de

38 P. Pierry Arrau (2000). 
un régimen específico de responsabilidad del Estado, como es el caso de los tribunales de justicia en materia no penal, desde que la norma constitucional especial solo da cobertura, en los términos en que está expuesta, a los daños derivados de ciertas actuaciones de los tribunales en el ámbito criminal ${ }^{39}$. Así, la responsabilidad del Estado por actos dańosos derivados de la justicia civil, de familia o laboral tendrá como régimen general de responsabilidad también el de la falta de servicio, pero por aplicación supletoria y extensiva de las reglas de responsabilidad extracontractual del Código Civil y no la del art. 42 de la LOCBGAE.

En todo caso, en aquellos casos en que el ordenamiento jurídico chileno regula la responsabilidad del Estado por la actuación de algún órgano público que no forma parte de la Administración del Estado, como sería el caso del Ministerio Público (art. 5º de la Ley 19.640, Ley Orgánica Constitucional del Ministerio Público $)^{40}$, la interpretación que se ha hecho del precepto legal específico es siguiendo en parte el criterio de imputación de responsabilidad por falta de servicio, aunque en este caso en términos más estrictos, considerando los términos específicos empleados por el legislador en esta materia. En este sentido, la Corte Suprema ha señalado en estos casos:

[...] que es claro que el art. $5^{\circ}$ de la Ley 19.640 establece un estatuto especial de responsabilidad extracontractual en que el título de imputación es el de "conductas injustificadamente erróneas o arbitrarias» del Ministerio Público. Tal como lo ha sostenido la jurisprudencia y la doctrina, se trata de un factor de atribución de responsabilidad mucho más restrictivo que el de los supuestos generales de la responsabilidad administrativa o de falta de servicio, respondiendo el primero más bien a un modelo de culpa o negligencia grave. En otras palabras, se debe estar ante un error craso y manifiesto, que no tenga sustento en un motivo plausible.

39 La Constitución Política de la República establece en el art. 19 No7 letra i, a propósito de la regulación del derecho fundamental a la libertad personal y la seguridad individual lo siguiente: «Una vez dictado sobreseimiento definitivo o sentencia absolutoria, el que hubiere sido sometido a proceso o condenado en cualquier instancia por resolución que la Corte Suprema declare injustificadamente errónea o arbitraria, tendrá derecho a ser indemnizado por el Estado de los perjuicios patrimoniales y morales que haya sufrido. La indemnización será determinada judicialmente en procedimiento breve y sumario y en él la prueba se apreciará en conciencia».

$40 \mathrm{El}$ art. 5 de la referida ley dispone: «El Estado será responsable por las conductas injustificadamente erróneas o arbitrarias del Ministerio Público. La acción para perseguir esta responsabilidad patrimonial prescribirá en cuatro años, contados desde la fecha de la actuación dañina. En todo caso, no obstará a la responsabilidad que pudiese afectar al fiscal o funcionario que produjo el daño, $y$, cuando haya mediado culpa grave o dolo de su parte, al derecho del Estado para repetir en su contra». 


\section{EL CONTENIDO DE LA «FALTA DE SERVICIO» COMO CRITERIO CLAVE DE IMPUTACIÓN DE RESPONSABILIDAD}

Ahora bien, la "falta de servicio" ha sido tradicionalmente definida por nuestra jurisprudencia, siguiendo la doctrina y jurisprudencia francesa, como aquella circunstancia que se presenta cuando «los órganos o agentes estatales no actúan debiendo hacerlo, o cuando su accionar es tardío o defectuoso, provocando, en uno u otro caso, o en concurrencia total o parcial, un daño a los usuarios o beneficiarios, del respectivo servicio público» (Sentencia Excma. Corte Suprema, «Hernández con Servicio de Salud de Concepción», Rol 1290-2002, de 30 de abril de 2003).

Así, el máximo tribunal de la República ha reiterado la existencia de las tres hipótesis que configurarían la "falta de servicio" en nuestro medio y la forma cómo este se concreta. Así, la Corte señala que, para establecerla:

[...] debe considerarse la actuación de la administración en relación a los medios de que dispone para ello. Se trata pues de un deber de actuación en concreto, tomando en consideración las particularidades de cada organismo administrativo. Fue justamente ese el espíritu del legislador, según es posible advertir del informe de la Comisión de Estudio de las Leyes Constitucionales de fecha 6 de diciembre de 1983, dirigido al Presidente de la República, el que al referirse al mal funcionamiento del servicio, en la página 10, señala que éste existe cuando la Administración no cumple con su deber de prestar servicio en la forma exigida por el legislador, no obstante disponer de los recursos para ello y no concurrir ninguna causal eximente («Navarro Carvajal con Hospital Provincial Illapel», Rol 1126-2011, de 25 de noviembre de 2011).

En este sentido, la «falta de servicio» se entiende como un funcionamiento anormal del servicio u órgano público, en que su actividad se desarrolla «objetivamente» en forma contraria al ordenamiento jurídico. Así, para establecer la responsabilidad estatal se debe realizar un juicio de carácter comparativo-objetivo entre la actuación concreta del servicio público y un estándar normativo exigido, naciendo la obligación reparatoria estatal en la medida que no se hubiera satisfecho dicho estándar y con ello se hubiera producido un daño efectivo a un tercero. En este sentido, Cordero señala que «el juicio de responsabilidad en realidad atiende al establecimiento de la mala organización o el funcionamiento defectuoso del servicio, apreciando esas nociones en forma objetiva por referencia a lo que se está en derecho de exigir de un servicio público moderno, es decir, aquello que debe ser su comportamiento normal» ${ }^{41}$.

Ahora bien, este comportamiento normal o exigible al servicio público está conformado por el cumplimiento de las obligaciones o estándares de diligencia

41 L. Cordero Vega (2012), «La responsabilidad por falta de servicio y la jurisprudencia de la Corte Suprema», en La falta de servicio, Santiago: Abeledo-Perrot/Thomson Reuters. 
exigibles a la Administración del Estado, los cuales están determinados en cada caso por el legislador, la propia autoridad administrativa en reglas generales o la ciencia o arte de la actividad material concreta desarrollada por el órgano púbico. No obstante lo anterior, en muchas ocasiones estos estándares no están determinados expresamente, por lo que corresponde al juez construirlos con criterio de razonabilidad, de manera objetiva y abstracta, o bien de manera subjetiva, considerando las condiciones en que el servicio funciona (Cordero, 2012). Un buen ejemplo de lo anterior son los estándares establecidos en materia médica, en que los procedimientos correspondientes están establecidos a menudo en protocolos o guías de funcionamiento, ya sea emanados de los propios servicios de salud, del Ministerio de Salud o de las sociedades científicas propias de la disciplina.

\section{LA RESPONSABILIDAD POR «FALTA DE SERVICIO» EN LA ACTIVIDAD ADMINISTRATIVA FORMAL}

Como se señaló, la falta de servicio supone una vulneración del estándar legal establecido para la prestación del servicio público que se expresa en el no funcionamiento, funcionamiento tardío o deficiente. Estos tres supuestos se generan, por regla general, a partir de una actuación irregular de la Administración del Estado, que en el caso de la actividad formal, requieren por su propia naturaleza de la emisión de un acto administrativo ilegal que constituya el presupuesto de la lesión o daño al particular ${ }^{42}$.

De esta manera, en materia de actuación formal de la Administración, el estándar exigido para establecer la falta de servicio consiste prima facie en la contravención del principio de legalidad en la emisión del acto administrativo, lo que constituirá la base del incumplimiento y configuración posterior del anormal funcionamiento de la Administración o su falta de servicio. Solo a partir de ahí se podría dar lugar a la responsabilidad del ente público, ya que la ilegalidad del acto administrativo es el elemento que configura la «falta» del servicio público ${ }^{43}$.

Sin embargo, la doctrina discute sobre la procedencia de algún elemento adicional a la mera ilegalidad o infracción del ordenamiento por la actuación administrativa formal para que nazca la obligación reparatoria para el Estado, particularmente la culpa o dolo. Lo anterior es muy relevante, ya que la obligación indemnizatoria nacerá automáticamente a partir de la ilegalidad declarada o requerirá la acreditación de un elemento culposo adicional de la organización o sus agentes, considerando la habitualidad y periodicidad de la actividad administrativa.

En la doctrina comparada se discute acerca de la concurrencia de este elemento «culpa» en la actividad administrativa formal irregular para generar la res-

42 J. C. Ferrada Bórquez (2012), «Falta de Servicio y responsabilidad por actos administrativos», en La falta de servicio, Santiago: Abeledo-Perrot/Thomson Reuters, págs. 288-289

43

Ibid. 
ponsabilidad del Estado en un caso determinado, ya que constituiría una exigencia adicional al particular para obtener la reparación de los perjuicios sufridos ${ }^{44}$. Así, en el derecho francés o español se opta mayoritariamente, aunque con matices y precisiones, por no exigir este elemento "culpa», lo que difiere del derecho italiano, que pareciera inclinarse por exigir esta, estableciéndose eso sí una presunción de esta en la actividad irregular de la Administración del Estado. De este modo, la ilegalidad del acto administrativo sería un indicio de culpabilidad para efectos de la responsabilidad patrimonial que operaría como una presunción iuris tantum, correspondiendo a la Administración probar la diligencia o cuidado en la resolución administrativa irregular que constituye la fuente de responsabilidad. Es decir, la Administración del Estado podría haber generado una actuación ilegal razonable, lo que no llevaría a la responsabilidad de la misma ${ }^{45}$.

En el derecho chileno la situación se asemeja a lo sostenido por la doctrina mayoritaria italiana, en la medida que la responsabilidad estatal se funda en una "culpa del servicio". En efecto, la "falta de servicio" es un título de imputación que exige culpa —objetivada — de la Administración como presupuesto de la responsabilidad, por lo que se exige la concurrencia de aquella para establecer esta. En este sentido, en el derecho administrativo chileno, en principio, no cualquier acto administrativo ilegal dará lugar a la responsabilidad estatal, sino solo aquellos que, provocando daño al particular, puedan fundarse en un acto culposo del servicio público o de sus agentes.

En este contexto, en mi opinión, en el derecho chileno solo se dará lugar a la responsabilidad estatal si aquel acto administrativo ilegal dañoso proviene de la culpa del órgano administrativo o de sus agentes, es decir, no descansa en un fundamento razonable que explique la actuación contraria a derecho, o no atribuible a una causal de exoneración. De este modo, los actos administrativos aparentemente válidos, que los órganos administrativos de control o los tribunales estiman así, no generan, en principio, responsabilidad civil para la Administración del Estado, ya que no concurre la culpa exigida para la configuración de esta ${ }^{46}$.

Sin embargo, otros autores critican la postura recién expuesta, sosteniendo — siguiendo en ello muy de cerca al derecho francés- que algunos textos legales reconocen explícitamente en el derecho chileno una conexión entre ilegalidad y responsabilidad, como, por ejemplo, en los denominados reclamos de ilegalidad municipal y regional, que permiten al tribunal establecer el «derecho a los perjuicios", en el art. 151, letras h) e i) de la LOCM, y el art. 108, letras h) e i) de la Ley Orgánico-Constitucional de Gobierno y Administración Regional (en adelante, LOCGAR). Así, se señala que esto evidencia la pertenencia de la ilegalidad al género de la falta de servicio, por lo que el acto que infringe la ley

44 L. Medina Alcoz (2005), La responsabilidad patrimonial por acto administrativo, Madrid: Thomson/ Civitas, págs. 214 y ss.

45 Ibid.: 227-228.

46 Ferrada (2012). 
o la ejecuta deslealmente debe mirarse como una falta de servicio, dado que el respeto a la legalidad tiene un peso preponderante entre los deberes de servicio. Así, basándose en la jurisprudencia francesa consagrada en el fallo «Ville de Paris c/ Driancourt", se sostiene que "la falta de servicio debe necesariamente darse por establecida en presencia de un acto ilegal, desde que el respeto a la legalidad es uno de los primeros imperativos de actuación exigibles al Estado [...] siempre es exigible de la administración que tome una posición correcta frente a la legalidad y actúe conforme a ella» ${ }^{47}$.

Sin perjuicio de la discusión doctrinal, la jurisprudencia de la Corte Suprema ha apoyado la primera de las posturas antes expuestas, ya que ha establecido que no existe una vinculación necesaria entre «ilegalidad» y «falta de servicio», señalando que esta última solo está presente en la actividad administrativa formal cuando aquella (la ilegalidad) sea sustancial y no razonable. En este sentido, la Excma. Corte Suprema ha sostenido que:

[...] no toda ilegalidad necesariamente es constitutiva de falta de servicio, por cuanto las nociones de ilegalidad y falta de servicio son independientes. De este modo una medida ilegal, susceptible de anulación, no da siempre derecho a reparación, lo que resulta evidente por ejemplo tratándose de ilegalidades de forma, o de incompetencia cuando la misma medida hubiere podido ser adoptada por una autoridad competente. Lo mismo ocurre tratándose de errores de apreciación que puedan conducir a la anulación de un acto, o cuando la misma medida hubiera podido ser tomada empleando un procedimiento regular (Sentencia Excma. Corte Suprema, «Inmobiliaria San Andrés con Municipalidad de Villarrica», Rol 7.5222008, de 2 de agosto de 2010 ${ }^{48}$.

Así, para la Corte Suprema chilena parecieran existir vicios o irregularidades que no configuran un funcionamiento deficiente o anormal de la Administración del Estado, en términos de imputar responsabilidad a esta, lo que se explica en la ausencia de culpa o esencialidad de la infracción, descartándose con ello la «falta de servicio». Esto pareciera razonable ya que, de otra forma, cualquier ilegalidad de un órgano de la Administración del Estado llevaría envuelta la responsabilidad civil del Estado, lo que además de insostenible patrimonialmente para este, vuelve inocua la distinción entre ilegalidad y falta de servicio, haciendo de aquella una cláusula general de responsabilidad o el establecimiento en el derecho chileno de una culpa objetivada por la mera infracción legal.

47 J. M. Valdivia Olivares (2016), «Actos administrativos ilegales y responsabilidad del Estado", Doctrina y Enseñanza del Derecho Administrativo chileno: Estudios en homenaje a Pedro Pierry Arrau, Valparaíso: Ediciones Universitarias de Valparaíso, págs. 488-489.

48 Este criterio ha sido reiterado posteriormente en las sentencias «Pozo Saavedra con Municipalidad de Las Condes», Rol 3.706-2010, de 30 de enero de 2013, y «Sociedad Comercial e Industrial Titanium Limitada con Instituto Nacional de Deportes», Rol 2.795-2015, de 30 de septiembre de 2015. 


\section{EL RECHAZO A LA RESPONSABILIDAD SIN FALTA EN EL ORDENAMIENTO JURÍDICO CHILENO}

Otro de los temas relevantes en el régimen de responsabilidad del Estado en el derecho chileno es determinar si esta puede proceder excepcionalmente sin falta o por actos lícitos. Así, se trata de determinar si la actividad legítima de la Administración del Estado que genera daños a un particular puede ser fuente de responsabilidad patrimonial en el derecho chileno.

En Chile, la cuestión ha surgido en torno a la idea de que hay situaciones de limitación de derechos que no suponen formalmente una expropiación, pero que eventualmente podrían dar lugar a una indemnización por ser cuasi expropiatorias. Frente a esto, desde la dogmática se plantea la posibilidad de aplicar la teoría del sacrificio especial alemana, que entiende que el afectado ha sido tratado de manera desigual, y a favor de la comunidad toda, razón suficiente para restablecer el equilibrio con el pago de una indemnización ${ }^{49}$.

Sobre esta temática la jurisprudencia chilena ha tenido una evolución a lo largo de los ańos, y que en la actualidad tiene una respuesta clara: no cabe la indemnización por daños causados por actos jurídicos legítimos de la Administración y que expresan el poder legal de fijar el contenido del derecho de propiedad y concretar su función social, competiendo a la ley determinar el modo de gozar del derecho de dominio ${ }^{50}$.

En efecto, en un primer momento, se determinó la responsabilidad del Estado por su actuación legítima en razón de que «nadie puede ser privado de lo suyo si no es por sentencia judicial, o por expropiación» («Lapostol con Fisco», Sentencia de la Corte Suprema, 8 de enero de 1930). Esta tesis fue confirmada muchos años después (1984) en el ya legendario caso «Galletué con Fisco» —al que ya he hecho referencia-, en el que la Corte Suprema siguió una tesis similar resolviendo que «el Estado debía indemnizar los perjuicios en la propiedad de un particular como consecuencia de la adopción de medidas lícitas y legítimas cuando éstas imponen un gravamen de contenido singular que implica la prohibición de desarrollar una actividad que hasta el momento previo a la decisión era lícita, teniendo como fundamento la Constitución y la equidad» ${ }^{51}$.

Sin embargo, la Corte cambió su postura en el año 2004, donde precisó que el art. $4^{\circ}$ de la LOCBGAE «opera o tiene aplicación cuando los órganos de la Administración del Estado actúan fuera de la órbita de sus atribuciones, lo

49 J. Bermúdez Soto (2014), Derecho Administrativo General, Santiago: Thomson Reuters, págs. 614-615.

50 A. Quintanilla Pérez (2004), «Corte Suprema en caso Lolco: no hay responsabilidad estatal por actos lícitos. El ocaso de la doctrina Galletué», Revista de Derecho, Consejo de Defensa del Estado, 12, págs. 41-53.

51 L. Cordero Vega (2014), Actualidad Administrativa: decisiones destacadas del año 2013, Santiago: Legal Publishing. 
que en la especie no ha ocurrido y ni siquiera ha sido puesto en duda» ("Agrícola Lolco con Fisco», Rol 381-2004, 30 de diciembre de 2004). Esta jurisprudencia ha sido ratificada posteriormente, entre otras, en sentencias del año 2010 («Inmobiliaria Maullín Limitada con Fisco de Chile», Rol 552-2008, 5 de octubre de 2010), 2012 («Productos Fernández con Ministerio de Salud», Rol 9924-2010, 20 de noviembre de 2012), 2013 ( «Sociedad Esquerré Hermanos Limitada con I. Municipalidad de Concepción», Rol 4043-2013, 30 de diciembre de 2013) y 2016 («Bodegas San Francisco con Fisco», Rol 8324-2015, de 14 de junio de 2016), en todas las cuales ha excluido la responsabilidad del Estado de Chile sobre la base precisamente de la licitud de la actuación administrativa, afirmando que ella no puede establecerse sin texto legal expreso que así la consagre.

Así, queda claro que para la jurisprudencia chilena la actuación lícita del Estado no puede ser fuente de responsabilidad, porque la actividad desplegada no es antijurídica. Solo cabría la responsabilidad estatal entonces por acto lícito en el caso de que el ordenamiento jurídico así lo dispusiera expresamente, sin que la doctrina y la jurisprudencia entonces acepte formalmente un título general de imputación distinto a la actuación irregular. Así, la desigualdad ante las cargas públicas no termina de constituirse en un título válido de responsabilidad estatal, no obstante la existencia y reconocimiento de este derecho fundamental en el texto constitucional vigente (art. 19, 22).

\section{LOS REGÍMENES ESPECIALES DE RESPONSABILIDAD EN EL DERECHO CHILENO}

Sin perjuicio de lo antes expuesto, en el derecho chileno también se contemplan algunos regímenes especiales de responsabilidad del Estado aplicables a ciertas actividades $u$ organizaciones administrativas que difieren, al menos en parte, del régimen general ya descrito ${ }^{52}$. En este sentido puede tomarse como referencia las reglas especiales establecidas en el ordenamiento jurídico chileno en materia sanitaria, medioambiental, accidentes de tráfico por mal estado de las vías públicas o de su señalización o en materia de energía nuclear, en que el legislador ha creado normas específicas para regular esta materia.

Así, en materia sanitaria, por ejemplo, la Ley 19.966 dispuso una regla de responsabilidad sobre el mismo criterio de imputabilidad denominado "falta de servicio» (art. 38) ${ }^{53}$, lo que guarda una evidente similitud con el régimen general de responsabilidad del Estado. En este contexto, la jurisprudencia chilena ha de-

52 Ferrada (2004: 118-120).

53 El art. 38 de la Ley 19.966 señala: «Los órganos de la Administración del Estado en materia sanitaria serán responsables de los dańos que causen a particulares por falta de servicio. El particular deberá acreditar que el daño se produjo por la acción u omisión del órgano, mediando dicha falta de servicio». 
jado en claro que se trata en este caso de un sistema de responsabilidad subjetiva, de acuerdo al que el particular afectado deberá acreditar la imputación constitutiva de falta de servicio, el daño y la relación de causalidad entre ambos» (Corte Suprema, «Gutiérrez con Servicio de Salud Araucanía Sur», Rol 31.932-2014) ${ }^{54}$.

No obstante esto, esta ley, a diferencia del sistema general de responsabilidad del Estado, ha dispuesto expresamente reglas especiales sobre prescripción de la acción (art. 40), algunas causales de exoneración de responsabilidad (particularmente, las denominadas lex artis y los riesgos del desarrollo, art. 41), el establecimiento de la mediación obligatoria (art. 43), algunos criterios para fijar las indemnizaciones por daño moral (art. 42) y el procedimiento y ejercicio de la acción de repetición en contra de los funcionarios que hubieren causado el daño

Por otro lado, en materia ambiental, la Ley 19.300, sobre Bases Generales del Medio Ambiente, contempla un régimen de responsabilidad por daño ambiental distinto del general establecido en la LOCBGAE. Así, en esta materia se dispone un régimen subjetivo de responsabilidad sobre la base de la culpa o dolo (art. 51) ${ }^{55}$, pero con presunciones de culpa, lo que implica poner de cargo del autor del daño - en este caso, el órgano público- la prueba de su diligencia o cuidado (art. 52) ${ }^{56}$, morigerando entonces la prueba de la negligencia o intencionalidad, en su caso ${ }^{57}$. La aplicación de este régimen especial de responsabilidad, si bien fue objeto de alguna controversia doctrinal inicialmente (Bermúdez, 2002), pareciera que actualmente es pacífica su extensión a los órganos del Estado, atendida la naturaleza de los daños provocados y demandados a través de esta acción ${ }^{58}$ y las deficiencias o anomalías que son causantes del daño ${ }^{59}$. Así lo ha declarado, por ejemplo, la Corte Suprema y

54 En el mismo sentido, los casos «Lagos con Servicio de Salud Metropolitano Occidente», SCS Rol 24.556-2014; "Tapia Servicio de Salud Aconcagua», SCS Rol 28.749-2014; "Vásquez con Servicio de Salud Viña del Mar Quillota», SCS Rol 5.538-2014.

55 El art. 51 de esta ley dispone: «Todo el que culposa o dolosamente cause daño ambiental responderá del mismo en conformidad a la presente ley. No obstante, las normas sobre responsabilidad por daño al medio ambiente contenidas en leyes especiales prevalecerán sobre las de la presente ley. Sin perjuicio de lo anterior, en lo no previsto por esta ley o por leyes especiales, se aplicarán las disposiciones del Título XXXV del Libro IV del Código Civil».

56 El art. 52 de la Ley dispone que: «Se presume legalmente la responsabilidad del autor del daño ambiental, si existe infracción a las normas de calidad ambiental, a las normas de emisiones, a los planes de prevención o de descontaminación, a las regulaciones especiales para los casos de emergencia ambiental o a las normas sobre protección, preservación o conservación ambientales, establecidas en la presente ley o en otras disposiciones legales o reglamentarias. Con todo, sólo habrá lugar a la indemnización, en este evento, si se acreditare relación de causa a efecto entre la infracción y el daño producido». Bermúdez (2014: 394-397).

58 Bermúdez (2014: 395).

59 Femenías, J. (2017), «Los daños ambientales como única categoría jurídica cuya reparación regula la Ley 19.300», Revista Chilena de Derecho, 44, 1, págs. 295-304. 
el Tribunal Ambiental, en casos que ha aplicado la normativa ambiental a las municipalidades, en el caso de daños ambientales provocados por su omisión culposa («Fisco de Chile con I. Municipalidad de Lo Barnechea», Rol 3022-2015, 5 de enero de 2016) o manejo inadecuado de una planta de tratamiento ("Junta de Vecinos Villa Disputada de Las Condes con Municipalidad de Nogales», Segundo Tribunal Ambiental, Rol D-17-2015, 7 de julio de 2017), respectivamente.

Ahora bien, en materia de daños derivados de transporte y tránsito público, se dispone también en el derecho chileno de una regla especial que señala que las municipalidades o el Fisco son responsables de los daños que se causen por el mal estado de las vías públicas o de su falta o inadecuada señalización (art. 169 del DFL 1, de 2007, del Ministerio de Transportes y Telecomunicaciones, que fija el texto refundido, coordinado y sistematizado de la Ley 18.290$)^{60}$. Parte de la doctrina ha visto en esta norma una presunción de falta que pesa sobre el Fisco y las municipalidades, señalando que se trata de una presunción de funcionamiento defectuoso del servicio, correspondiendo al servicio público la prueba del funcionamiento adecuado (Pierry, 1984). Sin embargo, la norma citada contiene dos hipótesis diferenciadas - mal estado de las vías públicas o falta o inadecuada señalización-, siendo la primera de ellas un supuesto que se acerca bastante a un régimen de responsabilidad objetiva, en la medida que no exige la norma una actuación deficiente del órgano administrativo.

Por último, en materia de energía nuclear, la ley chilena (Ley 18.302) establece también un régimen especial en materia de responsabilidad, el que en este caso es claramente objetivo, atendidos los términos que utiliza para su configuración (art. 49) ${ }^{61}$. Así, en este caso, el legislador hizo una opción precisa por este régimen de responsabilidad probablemente motivado por el riesgo que genera el desarrollo de actividades de esta naturaleza, lo que se aplica no solo al Estado, sino también a los particulares que ejercen aquellas.

De este modo es posible apreciar que existen regímenes especiales de responsabilidad del Estado en el derecho chileno que se acercan o alejan del régimen general de responsabilidad por falta establecido en la Ley Orgánica Constitucional de Bases Generales de la Administración del Estado, todos los cuales son compatibles con el texto constitucional, en la medida que este entrega al legislador su estructuración concreta y ella no viene determinada por aquel.

60 El actual inciso quinto del art. 169 de la ley cita dispone: «La Municipalidad respectiva o el Fisco, en su caso, serán responsables civilmente de los daños que se causaren con ocasión de un accidente que sea consecuencia del mal estado de las vías públicas o de su falta o inadecuada señalización».

61 El art. 49 de la Ley 18.302 dispone: «La responsabilidad civil por daños nucleares será objetiva y estará limitada en la forma que establece esta ley». 


\section{LOS DAÑOS INDEMNIZABLES POR RESPONSABILIDAD DEL ESTADO}

\section{EL DAÑO MATERIAL}

La regla general en materia de reparación de los daños provocados por la actividad o inactividad estatal, como en materia de responsabilidad civil extracontractual en general, es su extensión a todo daño, pues no existen normas especiales ni razones jurídicas para discriminar entre la reparación civil y la administrativa ${ }^{62}$. En este contexto, la obligación reparatoria del Estado recae, en primer lugar, sobre los dańos materiales o patrimoniales, que son aquellos que afectan bienes que tienen un significado económico que expresa un valor de cambio, lo que se traduce en una disminución del activo (daño emergente) o en la imposibilidad de su incremento (lucro cesante).

En este punto, la jurisprudencia chilena ha sido pacífica, considerando en la determinación de la indemnización por este concepto todos los daños patrimoniales provocados por la actividad administrativa irregular, incluyendo bajo el daño emergente el valor del bien corporal destruido, los gastos médicos, los honorarios profesionales, la ejecución de ciertas obras o servicios, entre otros. Asimismo, en materia de lucro cesante se han considerado los ingresos que deja de percibir el particular por el daño sufrido, cualquiera sea la fuente de los mismos, siempre que este pueda acreditarse fehacientemente en el proceso y estén relacionados directamente con la actividad o inactividad estatal.

\section{EL DAÑO MORAL}

Sin embargo, es en lo relativo al daño moral donde la jurisprudencia relacionada con la responsabilidad del Estado ha avanzado de una manera más decidida y novedosa en el derecho chileno, superando el clásico concepto civil del pretium doloris (el "precio del dolor») y ha acogido desde ya hace largo tiempo un concepto más amplio vinculado a la "alteración o trastorno de las condiciones normales de vida o existencia» (Sentencia de la Corte de Apelaciones de Santiago, «Tirado con I. Municipalidad de La Reina», 1981). Esta ampliación del concepto del daño moral probablemente toma como referencia la jurisprudencia francesa de mediados del siglo XX sobre la materia, en que el perjuicio moral se identifica con la noción más amplia de "perturbaciones graves a las condiciones de existencia», alejándose de la concepción civil clásica ${ }^{63}$.

En términos análogos, la Ley 19.966 de 2004, que establece la responsabilidad del Estado en materia sanitaria, como ya se señaló, ha establecido algunas

62 Barros (2006: 502).

63 Vedel (1981: 324-326). 
reglas especiales para determinar el monto de las indemnizaciones por daño moral, ordenando al juez considerar la gravedad del daño y la modificación de las condiciones de existencia del afectado con el daño producido, atendiendo su edad y condiciones físicas (art. 41). Este nuevo parámetro legal evidentemente agrega una exigencia adicional al juez a la hora de justificar la apreciación del daño moral, con miras a que esta tenga un sustento coherente con el mérito del proceso, y no sea producto de la mera arbitrariedad judicial.

No obstante, la jurisprudencia no ha sido muy consistente en la aplicación de estos criterios legales para la determinación del daño moral en los casos de responsabilidad del Estado por actividad sanitaria, limitándose en muchos casos a aplicar los criterios clásicos del daño moral del ámbito civil. Así, la Corte Suprema ha sostenido que:

[...] en cuanto al dańo moral demandado por la cónyuge e hijos de la víctima directa, cabe consignar que su existencia se encuentra debidamente acreditada con el mérito de las declaraciones de los testimonios contestes presentados por la parte demandante y expuestas por el fallo revisado, de las cuales es posible concluir que los actores sufrieron dolor y aflicción por la muerte de un familiar muy cercano, pesar que constituye un daño inmaterial susceptible de ser indemnizado, estimando esta Corte ajustado al mérito de los antecedentes el monto regulado por el tribunal de primera instancia ("Campos con Servicio de Salud de Concepción», Rol 27.1752014, de 27 de abril de 2015).

Sin perjuicio de lo anterior, debe tenerse en cuenta otro elemento que puede resultar interesante para efectos de fijar un parámetro objetivo de cuantificación del daño moral, que son los montos máximos a pagar por los prestadores públicos en virtud del procedimiento de mediación establecido en la Ley 19.966. Sobre el particular, la Resolución Exenta 142 de 2005, del Ministerio de Salud, establece topes máximos a pagar por el Estado en caso de ciertos daños derivados de la actividad sanitaria, enunciándose límites en Unidades de Fomento ${ }^{64}$ de 3500 UF (140 000 dólares aproximadamente) en caso muerte de una persona, 3300 UF (132000 dólares aproximadamente) en caso de gran invalidez, 2500 UF (100 000 dólares aproximadamente) en caso de invalidez total, 2000 UF (80 000 dólares aproximadamente) en invalidez parcial y 1000 UF (40 000 dólares aproximadamente) por otros daños que generen incapacidad temporal.

Esta regulación de jerarquía reglamentaria puede ser considerada como un criterio de razonabilidad para determinar los parámetros aceptables dentro de los cuales se puede fijar una indemnización, constituyéndose en un límite a indemnizaciones excesivamente onerosas en contra del Estado. Sin embargo, los tribunales pueden es-

64 La sigla UF significa "Unidad de Fomento», y es una unidad de cuenta reajustable diariamente de acuerdo con la inflación, usada en Chile desde 1967, siendo su principal y original uso en los préstamos hipotecarios. El valor de la UF al 31 de octubre de 2018 es de $\$ 27.432,10$, que equivale aproximadamente a 40 dólares. 
tablecer otros valores a la hora de determinar la indemnización en un caso concreto, elevando los montos antes reseñados, lo que ha ocurrido frecuentemente en daños derivados precisamente de la actividad estatal en materia sanitaria, pero también en otro tipo de actividades o inactividades estatales dañosas, como las provenientes de la actividad irregular de las Fuerzas Armadas, la falta de diligencia en materia de evacuación de zonas de riesgo de tsunami o inundación, desaparición forzada de personas o dańos derivados del mal estado del alumbrado público, de los árboles de una plaza o del estado de las vías públicas. En todos estos casos, la jurisprudencia ha fijado valores más altos, especialmente en casos de muerte o desaparición forzada de una persona, llegando a indemnizaciones de más de 1000000 dólares («Sepúlveda y otros con Fisco de Chile», Rol 2471-2018, de 6 de marzo de 2018).

\section{EL DAÑO COMO «PÉRDIDA DE CHANCE»}

Un criterio novedoso que ha venido planteando la jurisprudencia de la Corte Suprema en el último tiempo en materia de daño es la utilización del concepto de "pérdida de chance», para efectos de cuantificar el monto de la indemnización, pero también para establecer el nexo causal entre el acto u omisión y el daño. Esto ha sido especialmente utilizado en casos de responsabilidad del Estado por actividad ilegal en un procedimiento administrativo de contratación pública ( Sociedad Comercial e Industrial Titanium Limitada con el Instituto Nacional de Deportes», Rol 2795-2015, de 30 de septiembre de 2015), aunque también ha recurrido a aquel para determinar el nexo causal y el monto a indemnizar en caso de daños provenientes de mala praxis en procedimientos médicos ( Sarabia con Servicio de Salud de Iquique y otros», Rol 9481-2016, de 22 de septiembre de 2016) o de terremotos o tsunamis ( Escalona y otros con Fisco de Chile», Rol 12169-2017, de 9 de noviembre de 2017).

Ahora bien, en los casos de irregularidades en procedimientos de contratación pública, la Corte Suprema ha establecido como daño un porcentaje de la oferta formulada por el actor en su propuesta económica (5\%) y que ha sido irregularmente excluida del concurso público, sin que se justifique claramente el criterio y el guarismo utilizado. Así, la Corte Suprema ha señalado que «es razonable concluir que este actuar indebido de la Administración le ha significado a la actora la pérdida de una chance, de una oportunidad legítima de ganancia eventual, respecto de la cual es posible hacer una avaluación de los perjuicios fijándola prudencialmente en el equivalente al cinco por ciento del monto de la oferta hecha por su parte para adjudicarse la licitación» («Sociedad Comercial e Industrial Titanium Limitada con el Instituto Nacional de Deportes», Rol 27952015, de 30 de septiembre de 2015).

Por el contrario, en el caso de daños (muertes) derivados de un terremoto y/o tsunami, por no aviso a la población sobre la alerta correspondiente, no obstante tener la información pertinente, la pérdida de chance no opera tanto en la cuantificación del daño mismo, sino en su conexión con la inactividad estatal 
acusada. Así, la Corte Suprema, citando al profesor Mauricio Tapia, ha señalado que «entre nosotros» se ha sostenido que:

La pérdida de una chance se encuentra entre estas últimas hipótesis (cuando no se sabe lo que habría ocurrido en el futuro de no haberse cometido el hecho ilícito), esto es, incide en la frustración de una expectativa de obtener una ganancia o de evitar una pérdida. Pero, a diferencia del daño eventual, en los casos de pérdida de una oportunidad puede concluirse que efectivamente la víctima tenía oportunidades serias de obtener el beneficio esperado o de evitar el perjuicio, tal como ya se ha mencionado. Y luego ańade: En el caso concreto, el vínculo de causalidad, se relaciona estrechamente con la teoría en análisis, pues aplicando las ideas expuestas en los considerandos anteriores se concluye que la relación causal se vincula con la circunstancia de privar a las víctimas de una oportunidad de poner a resguardo su vida, cuestión que efectivamente podrían haber realizado si hubiesen recibido la información de riesgo de tsunami oportunamente. En efecto, la omisión de la entrega oportuna de la información sólo puede relacionarse causalmente con la pérdida de la oportunidad de alejarse de las zonas de riesgos antes de la llegada de las olas que determinan la muerte o afectación de las personas, cuestión que a su turno se relaciona con la opción que tienen aquellos que demandan en su calidad de víctimas por repercusión o rebote de haber contado por más tiempo con su ser querido.

\section{LA PRESCRIPCIÓN DE LA ACCIÓN INDEMNIZATORIA}

\section{LA REGLA GENERAL DEL CÓDIGO CIVIL}

Una última cuestión que es necesario abordar, aunque sea sucintamente en materia de responsabilidad del Estado, es la regulación de la prescripción de las acciones de responsabilidad del Estado en el derecho chileno. Esta materia ha estado marcada en los últimos veinticinco ańos por la inexistencia de una regla específica en materia de responsabilidad del Estado, lo que ha generado una discusión sobre la aplicación o no de las normas contenidas en el Código Civil que sí contienen una regla en esta materia. En efecto, el art. 2332 del Código Civil chileno, ubicado dentro del título XXXV de los «delitos y cuasidelitos», establece que «las acciones que concede este título por daño o dolo, prescriben en cuatro años contados desde la perpetración del acto». Pues bien, la discusión doctrinal y jurisprudencial se ha centrado en determinar si dicha regla tiene aplicación o no en materia de responsabilidad del Estado.

La respuesta a dicha interrogante discurre por dos caminos. Por un lado, la concepción estatutaria del derecho administrativo y la comprensión de este como un sistema jurídico autónomo. Por otro, la aplicación de las normas civiles en general en los asuntos de derecho administrativo, ya sea como norma supletoria o subsidiaria, en ciertos casos. 
La jurisprudencia de la Corte Suprema en una primera época, siguiendo la doctrina clásica dominante ${ }^{65}$, planteó la exclusión de la aplicación de dicha regla, en la medida que la responsabilidad del Estado era una materia distinta de la responsabilidad civil extracontractual, no pudiendo aplicar las reglas de esta a aquella. Así, la Corte Suprema, a partir de afirmar la imprescriptibilidad de la acción de nulidad de derecho público (criterio jurisprudencial aplicado por la jurisprudencia hasta el día de hoy), deduce la imprescriptibilidad de la acción de responsabilidad civil asociada a la primera, entendiendo que esta es una responsabilidad constitucional («Brian de Diego con Fisco de Chile», Rol 2834-1999, de 19 de abril de 2000).

Sin embargo, a partir del año 2002 ("Domic con Fisco», Rol 4753-2001, de 15 de mayo de 2002), la jurisprudencia de la Corte Suprema ha venido sosteniendo la prescriptibilidad de la acción de responsabilidad en contra del Estado, siguiendo el criterio ya marcado por la misma Corte sobre prescriptibilidad general de las acciones patrimoniales en contra del Estado («Aedo con Fisco», Rol 8522000, de 27 de noviembre de 2000). En este sentido, la Corte Suprema declaró que «el hecho de que ciertas responsabilidades se sometan al Derecho Público no obsta a que ellas puedan extinguirse por el transcurso del tiempo, en conformidad a las disposiciones que se comprenden en el mismo sector del Derecho, porque lo cierto es que la prescripción no es ajena a esas normativas, atendido su carácter universal y puede operar en todas las disciplinas que pertenecen al Derecho Público, salvo que la ley o la índole de la materia determinen lo contrario» («Domic con Fisco", Rol 4753-2001, de 15 de mayo de 2002).

Este criterio lo ha reiterado la Corte Suprema en fallos posteriores, y constituye una afirmación categórica de la aplicación de las normas civiles en materia de prescripción, no como norma supletoria, sino como norma de aplicación directa, en virtud de lo establecido en el art. 2497 del Código Civil ${ }^{66}$. Así, el carácter estatutario del derecho administrativo no impide la aplicación de normas civiles a los asuntos administrativos, más aún cuando aquellas consideran su aplicación al Estado y otros entes públicos, como sería en esta materia, aunque también ello se extiende a otros ámbitos del derecho administrativo ${ }^{67}$.

\section{LA EXCEPCIONALIDAD EN MATERIA DE DERECHOS HUMANOS}

La regla anterior se aplicó inicialmente también en materia de derechos humanos, es decir, en casos en que el daño estaba configurado por la desaparición forzada de una persona. Así, la Corte Suprema sostuvo que:

65 Soto (1984: 127-138)

66 El art. 2497 del Código Civil señala que «las reglas relativas a la prescripción se aplican igualmente a favor y en contra del Estado, de las iglesias, de las municipalidades, de los establecimientos y corporaciones nacionales, y de los individuos particulares que tienen la libre administración de lo suyo».

67 Ferrada (2007: 116-118). 
[...] es necesario recordar que, estando acreditado que la detención y desaparición de don Juan Chamorro Arévalo, con intervención de funcionarios del Estado, tuvieron lugar bajo el imperio de la Constitución Política de 1925 y debiendo la responsabilidad del Estado derivada de esa situación regirse por normas de Derecho Público, lo cierto es que ninguna de estas condiciones obsta a que las acciones conducentes a la reparación del daño moral causado a familiares de la víctima de estas actuaciones puedan extinguirse por la prescripción, merced a las normas pertinentes a la materia que consulta el ordenamiento positivo. [Y luego añadió:] Que, efectivamente, la prescripción extintiva tiene cabal aplicación en el ámbito del Derecho Público, como lo denotan los preceptos que la regulan en distintas ramas de este sector, v.gr., los que hacen cesar la responsabilidad disciplinaria de diferentes categorías de funcionarios estatales, según los arts. 151 letra d) y 152 de la Ley 18.834; 153 letra d) y 154 de la Ley 18.883 y 156 del decreto con fuerza de Ley 1, de 1997, de Guerra y las que inciden en el campo tributario, con arreglo al Título VI del Libro IV del Código del ramo, entre otras normas semejantes («Pizani Burdiles y otra con Fisco», Rol 1234-2002, de 15 de abril de 2003).

Este criterio fue reiterado por la Corte Suprema durante una década, llegando incluso a dictar la Corte una sentencia de unificación del pleno, ante las divergencias que se producían entre la sala penal y la constitucional sobre la materia. En este sentido, el pleno de la Corte Suprema señaló en su momento que los tratados internacionales en materia de derechos humanos no:

[...] establece(n) la imprescriptibilidad genérica de las acciones orientadas a obtener el reconocimiento de la responsabilidad extracontractual del Estado o de sus órganos institucionales. Así, la propia Convención Americana de Derechos Humanos no contiene precepto alguno que consagre la imprescriptibilidad alegada por el recurrente. Además, ninguna de las disposiciones citadas en el recurso excluye respecto de la materia en controversia la aplicación del derecho nacional. En efecto, el art. $1^{\circ}$ sólo consagra un deber de los Estados miembros de respetar los derechos y libertades reconocidos en esa Convención y garantizar su libre y pleno ejercicio, sin discriminación alguna; y el art. 63.1 impone a la Corte Interamericana de Derechos Humanos un determinado proceder si se decide que hubo violación a un derecho o libertad protegido («González Galeno con Fisco de Chile», Rol 10.665-2011, de 21 de enero de 2013).

Sin embargo, este criterio ha cambiado en los últimos años, producto de la radicación de los casos de responsabilidad del Estado derivados de crímenes de lesa humanidad en la sala penal de la Corte Suprema (Segunda Sala) y no en la sala de Derecho Público (Tercera Sala). Así, por acuerdo de la misma Corte, todos los juicios penales o civiles en que se discute la responsabilidad del Estado son conocidos por la sala penal de esta, la que invariablemente ha venido sosteniendo la imprescriptibilidad de la acción de responsabilidad en contra del Estado proveniente de la violación grave de los derechos humanos, pero ello no por la no aplicación del Código Civil, sino por la aplicación preferente de las normas contenidas en tratados internacionales sobre esta materia. 
En este sentido, la Corte Suprema ha señalado recientemente (6 de marzo de 2018), confirmando un criterio que viene afirmándose de forma invariable al menos desde el año 2013, que:

[...] más allá de lo razonado por los jueces ad quem, reiterada jurisprudencia de esta Corte precisa que, tratándose de un delito de lesa humanidad - lo que ha sido declarado en la especie-, cuya acción penal persecutoria es imprescriptible, no resulta coherente entender que la correlativa acción civil indemnizatoria esté sujeta a las normas sobre prescripción contempladas en la ley civil interna, ya que ello contraría la voluntad expresa manifestada por la normativa internacional sobre Derechos Humanos, integrante del ordenamiento jurídico nacional, en armonía con el inciso segundo del art. $5^{\circ}$ de la Carta Fundamental. [Y añade:] Que, además, la acción civil aquí deducida por los demandantes en contra del Fisco, tendientes a conseguir la reparación íntegra de los detrimentos ocasionados, encuentra su fundamento en los dogmas generales del Derecho Internacional de los Derechos Humanos y su consagración normativa en los tratados internacionales ratificados por Chile, los cuales obligan al Estado a reconocer y proteger este derecho a la reparación completa, en virtud de lo ordenado en los arts. $5^{\circ}$, inciso segundo, y $6^{\circ}$ de la Constitución Política de la República («Sepúlveda y otros con Fisco de Chile», Rol 2471-2018).

\section{A MODO DE CONCLUSIÓN}

De lo antes expuesto creo que se puede concluir inequívocamente que en el derecho chileno actual el régimen de responsabilidad del Estado descansa sobre la falta o la culpa del servicio, criterio de imputación que se ha extendido no solo a aquellos órganos de la Administración del Estado regidos por la LOCBGAE, sino a todos los órganos del Estado en general, salvo que exista norma legal específica en contrario.

Este criterio de imputación ha tenido tal impacto en el derecho chileno que ha impedido incluso el reconocimiento de otros criterios de imputación por vía jurisprudencial, no acogiéndose en el derecho chileno la responsabilidad objetiva del Estado, sin culpa o falta, por desigualdad ante las cargas públicas o por sacrificio especial, salvo texto legal expreso, como sí ocurre en otros ordenamientos de referencia.

En este contexto, los principales desafíos del régimen chileno de responsabilidad del Estado son su flexibilización, admitiendo presunciones de falta, nuevos títulos de imputación y reglas más precisas de determinación de los daños indemnizables. 
